\title{
PERANCANGAN ULANG TATA LETAK FASILITAS PABRIK DALAM UPAYA EFISIENSI MATERIAL HANDLING DI UD. DONESI
}

\author{
Intan Nurhaliza Irmanto, M. Indra Darmawan, dan Yuliana Ningsih \\ Jurusan Teknologi Industri Pertanian, Politeknik Negeri Tanah Laut \\ Email: mindradarmawan@politala.ac.id
}

\begin{abstract}
ABSTRAK
UD. Donesi merupakan suatu industri yang bergerak dibidang pembuatan kue kering tradisional. Saat ini kondisi tata letak fasilitas produksi di UD. Donesi masih kurang efisien dalam pengaturan material handling. Penelitian ini bertujuan untuk mendapatkan rancangan tata letak fasilitas pabrik yang efisien dengan menggunakan metode ARC dan menganalisis secara kuantitatif dengan meminimalkan material handling, waktu dan menghitung ongkos material handling Pendekatan yang digunakan pada perancangan ulang tata letak fasilitas produksi di UD. Donesi dengan menggunakan analisis kualitatif menggunakan Activity Relationship Chart (ARC) dan analisis kuantitatif melalui perhitungan jarak, waktu dan ongkos material handling dalam menentukan keberhasilan proses perancangan ulang tersebut. Hasil yang diperoleh dari rancangan Layout usulan berdasarkan analisis ARC yaitu jarak material handling berkurang sebesar 68,5 $\mathrm{m}$ dan waktu material handling menjadi 358,46 detik serta ongkos material handling $\mathrm{Rp} 20.664$.

Kata kunci-ARC; jarak material handling; ongkos material handling; waktu material handling
\end{abstract}

\section{PENDAHULUAN}

Tata letak pabrik merupakan salah satu faktor yang berperan penting dalam peningkatan efisiensi industri. Pengaturan tata letak fasilitas produksi dan area kerja yang tepat dapat meningkatkan produksi dan performansi pekerja. Tata letak fasilitas yang baik akan mempengaruhi sistem produksi yang akan menambah kapasitas produksi (Yulianti dkk., 2014)

Perancangan tata letak meliputi pengaturan tata letak fasilitas-fasilitas operasi dengan memanfaatkan area yang tersedia untuk penempatan mesin-mesin, bahan-bahan perlengkapan untuk operasi, dan semua peralatan yang digunakan dalam proses operasi. Salah satu tujuan dari perancangan tata letak fasilitas produksi adalah penggunaan ruangan yang lebih efektif (Setiyawan dkk., 2017) dan meminimumkan kerusakan persediaan (Maydah, Darmawan, dan Ilmannafian, 2020). Penggunaan ruangan akan efektif jika mesin-mesin atau fasilitas pabrik lainnya disusun atau diatur sedemikian rupa dengan mempertimbangkan jarak minimal antar mesin atau fasilitas produksi, dan aliran perpindahan material ini merupakan hal penting terutama bagi industri berkembang seperti Usaha dagang Donesi.

Usaha dagang (UD) Donesi merupakan suatu industri yang bergerak di bidang pembuatan kue kering tradisional. Produk yang dihasilkan oleh UD Donesi beraneka ragam jenisnya seperti plintiran, akar pinang, stik keju, pangsit, pastel, keciput dan bidara. Secara keseluruhan proses pembuatan produk tersebut mayoritas memiliki alur pembuatan yang sama, yaitu pengadonan, pencetakan, penggorengan dan proses pengemasan. Tata letak pabrik UD. Donesi terbagi menjadi 2 bangunan pabrik yang terpisah bangunan seperti yang ditunjukkan pada Gambar 1. Pemisahan produksi dalam dua bangunan berbeda ini membuat jarak perpindahan material menjadi tidak efisien.

Bagi perusahaan yang sedang berkembang seperti UD. Donesi diperlukan adanya analisis lebih mendalam untuk dapat memecahkan masalah yang dihadapi oleh perusahaan tersebut. Analisa dilakukan pada rancangan tata letak fasilitas dengan menggunakan metode Activity Relationship Chart (ARC) dimana akan dibuat diagram keterkaitan antar fasilitas proses produksi. Metode ARC atau derajat hubungan keterkaitan adalah suatu teknik untuk merencanakan keterkaitan antara stasiun kerja berdasarkan derajat hubungan kegiatan yang dinyatakan penilaian dengan menggunakan huruf dan angka yang menunjukkan alasan untuk sandi tersebut. Penggunaan metode ARC dalam perancangan ulang tata letak pabrik dapat meningkatkan efisiensi dengan memperpendek jarak, waktu pengerjaan yang optimal, sehingga kinerja perusahaan menjadi lebih efektif dan efisien (Safitril dkk., 2017). Menurut penelitian Erni dkk. (2013), penggunaan rancang ulang tata letak menggunakan ARC dapat meningkatkan efisiensi sebesar $37 \%$. 


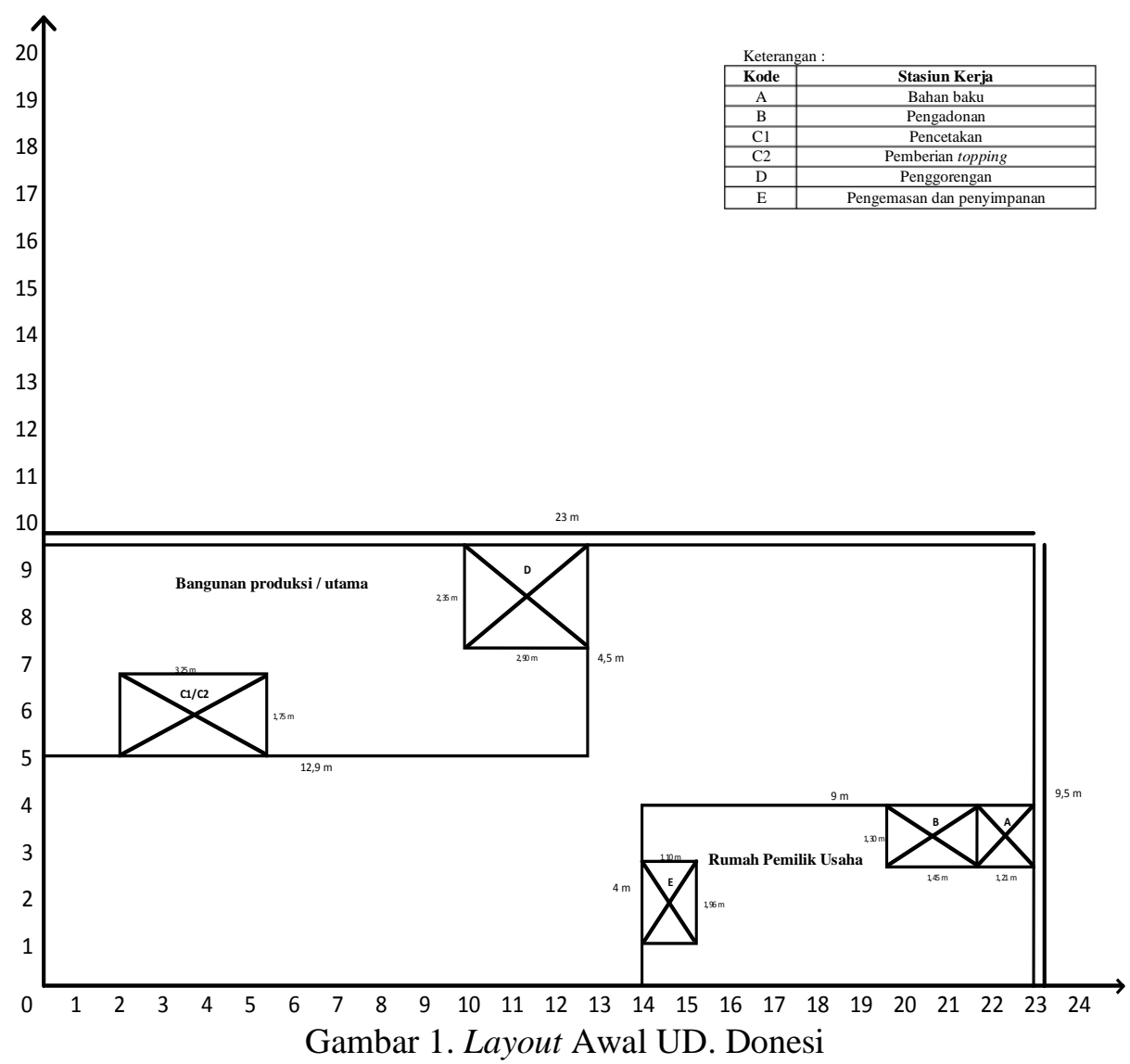

Rancangan ulang tata letak pada area produksi di UD. Donesi akan dilakukan dengan mempertimbangkan luas area produksi, pola tata letak fasilitas produksi, produktivitas kinerja karyawan, dan penempatan fasilitas-fasilitas sesuai dengan hubungan keterkaitan antar departemen serta ongkos material handling. Tujuan dari penelitian ini adalah mendapatkan rancangan tata letak fasilitas pabrik yang efisien dengan menggunakan metode ARC dan menganalisis secara kuantitatif dengan meminimalkan material handling, waktu dan menghitung ongkos material handling.

\section{METODOLOGI PENELITIAN}

\section{A. Pengumpulan Data}

Teknik yang digunakan memperoleh data-data penunjang antara lain: studi pustaka yang merupakan teknik pengumpulan data dengan melakukan telaah pustaka, eksplorasi, dan mengkaji berbagai literatur pustaka seperti jurnal, masalah, artikel, internet, dan sumber-sumber lainnya yang berkaitan dengan penelitian. Penelitian lapangan (field research), yaitu langsung ke objek penelitian dengan cara:

a) Observasi

Dalam observasi dilakukan dengan cara pengamatan secara langsung mengenai pelaksanaan pengerjaan. Dalam penelitian ini, dilakukan wawancara, pengisian kuesioner dan pengukuran secara langsung pada lantai proses pengolahan UD. Donesi.

b) Studi Pustaka

Studi pustaka dengan melakukan pengkajian berbagai literatur pustaka seperti jurnal, masalah, artikel, internet, dan sumber-sumber lainnya yang berkaitan dengan penelitian.

c) Dokumentasi

Dokumentasi dengan mengumpulkan data dengan cara mencatat dokumen yang berhubungan dengan penelitian ini. 


\section{B. Pengolahan data}

Metode yang digunakan dalam penelitian ini adalah Activity relationship chart (ARC) dan analisis kuantitatif mengenai material handling. Langkah yang dilakukan pada penelitian ini adalah sebagai berikut:

1. Identifikasi Alur Proses Pengolahan Produk (Astuti dkk. (2017))

Identifikasi alur proses produksi dilakukan sebagai patokan dalam merancang ulang tata letak produksi. Alur proses produk UD. Donesi yang terpilih adalah produk dengan alur produksi terpanjang. Hal ini didasari oleh proses pengolahan aneka produk UD. Donesi menggunakan adonan yang sama. Pemilihan alur terpanjang ini juga diharapkan agar memperoleh analisis yang menyeluruh untuk perancangan ulang tata letak.

2. Analisis Activity Relationship Chart (ARC) (Amalia dkk. (2017) dan Pratiwi dkk. (2012))

Analisis menggunakan metode Activity Relationship Chart (ARC) harus dimulai dengan penentuan tingkat kepentingan hubungan antar aktivitas hubungan yang didapat dari hasil wawancara dan pengisian kuesioner. Kemudian hasil kuesioner Ini dapat digambarkan dengan lambang, warna atau huruf . Karakteristik hubungan antar aktivitas ditunjukan pada Tabel 1.

Tabel 1. karakteristik hubungan antar aktivitas

\begin{tabular}{cl}
\hline $\begin{array}{c}\text { Derajat } \\
\text { kedekatan }\end{array}$ & \multicolumn{1}{c}{ Deskripsi } \\
\hline $\mathrm{A}$ & Sangat penting untuk \\
$\mathrm{E}$ & didekatkan \\
$\mathrm{I}$ & Penting untuk didekatkan \\
$\mathrm{O}$ & Cukup/bias \\
$\mathrm{U}$ & Tidak penting \\
\hline
\end{tabular}

Selain simbol-simbol tersebut, responden juga akan mencantumkan alasan yang memberi penjelasan mengapa simbol atau huruf tersebut digunakan. Alasan harus sesuai dengan tingkat hubungan aktivitas yang digambarkan seperti yang ditunjukan pada Tabel 2.

\begin{tabular}{|c|c|}
\hline No & Alasan \\
\hline 1 & Urutan aliran kerja \\
\hline 2 & Aliran material \\
\hline 3 & Menggunakan tenaga kerja yang sama \\
\hline 4 & $\begin{array}{l}\text { Sumber kontaminasi (bising,bau,debu, } \\
\text { kotor) }\end{array}$ \\
\hline 5 & Keselamatan dan kenyaman kerja \\
\hline 6 & Tidak ada hubungan kerja \\
\hline
\end{tabular}

Setelah menetukan hubungan antar aktivitas dan alasannya maka dibuat lah diagram ARC Selanjutnya akan dibuat rancangan layout usulan berdasarkan hasil pengukuran langsung luas lantai produksi dan hasil analisis ARC tersebut.

3. Penentuan Titik Koordinat Stasiun Kerja layout awal (Amalia dkk. (2017))

Penetuan titik koordinat stasiun kerja Layout awal sebelum dilakukan pengukuran jarak rectilinier yang harus dilakukan adalah menentukan titik koordinat tiap stasiun kerja.

4. Perhitungan total jarak material handling layout Usulan (Astuti dkk. (2017))

Perhitungan jarak material handling antar stasiun layout usulan setelah analisis ARC yang berkaitan. Jarak antar stasiun kerja dapat diketahui dengan melakukan menentukan pusat antara stasiun kerja. Selanjutnya adalah perhitungan jarak dengan menggunakan sistem jarak siku 
(rectilinear), yaitu jarak yang diukur antara pusat stasiun kerja satu dengan pusat stasiun kerja lainnya Astuti dkk. (2017). Rumus yang digunakan adalah sebagai berikut:

$d i j=[(\mathrm{Xi}-\mathrm{Xj})+(\mathrm{Yi}-\mathrm{Yj})]$

$$
\text { Keterangan: } \begin{aligned}
\mathrm{Xi} & =\text { koordinat } \mathrm{x} \text { pada pusat fasilitas } \mathrm{i} \\
\mathrm{Yi} & =\text { koordinat y pada pusat fasilitas } \mathrm{i} \\
\mathrm{dij} & =\text { jarak atara pusat fasilitas } \mathrm{i} \text { dan } \mathrm{j}
\end{aligned}
$$

\section{Perhitungan Ongkos Material Handling Layout Usulan (Astuti dkk. (2017))}

Perhitungan ongkos material handling adalah dengan menentukan ongkos dari stasiun satu ke stasiun yang lain pada layout usulan dengan menggunakan alat angkut manusia. Rumus yang digunakan sebagai berikut:

Ongkos Material Handling $(\mathrm{OMH})$ per hari = jarak tempuh tiap hari $\times \mathrm{OMH} / \mathrm{meter}$

\section{Perhitungan Waktu Material Handling Layout Usulan (Pramesti dkk. (2019))}

Waktu perpindahan bahan merupakan hal yang penting dalam proses produksi. Perhitungan waktu berfungsi untuk mengetahui total waktu perpindahan dari statsiun satu ke stastiun lainnya pada layout usulan Pramesti dkk. (2019). Rumus yang digunakan adalah sebagai berikut:

Waktu $=$ total waktu per meter $\times$ total jarak antar stasiun

\section{Perbandingan Layout Awal dan Layout Usulan (Astuti dkk. (2017))}

Dilakukan perbandingan total jarak, waktu dan ongkos material handling antara layout awal dan layout usulan dengan melihat hasil perhitungan jarak, waktu dan ongkos material handling dari masing-masing layout Astuti dkk. (2017). Layout yang memiliki hasil yang minim maka layout tersebut adalah layout yang lebih efektif dan efisien bagi industri UD. Donesi.

\section{HASIL DAN PEMBAHASAN}

\section{A. Alur Proses Pengolahan Produk (Kue Bidara)}

UD. Donesi merupaka sebuah industri makanan yang memeproduksi kue kering tradisional berupa akar pinang, pastel, plintiran,bidara, kec iput Dari semua produk yang dihasilkan UD. Donesi produk yang memiliki alur proses yang terpanjang adalah kue bidara. Alur proses produksi kue Bidara disajikan pada Gambar 2.

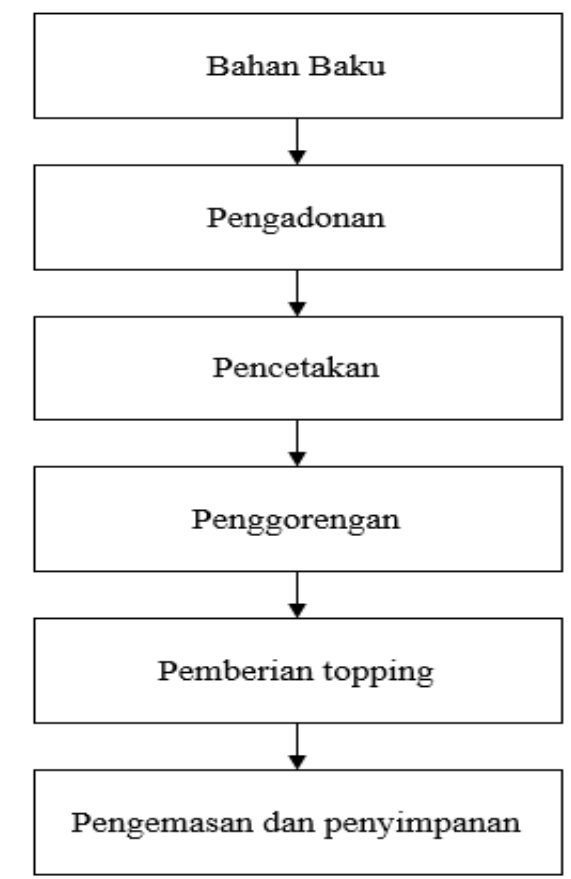

Gambar 2. Alur Proses Produksi Kue Bidara 


\section{B. Analisis Activity Relationship Chart (ARC)}

ARC merupakan peta keterkaitan aktivitas yang berupa belah ketupat yang terdiri dari 2 bagian yaitu bagian atas yang menunjukan simbol derajat keterkaitan antara dua stasiun sedangkan bagian bawah merupakan alasan yang dipakai untuk mengukur derajat keterkaitan. Hasil yang didapat dapat dilihat pada Gambar 3.

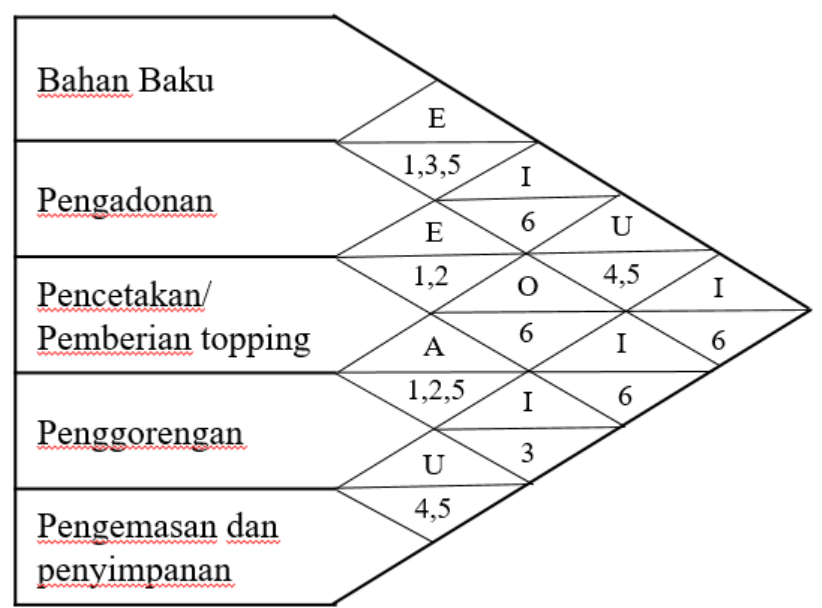

Gambar 3. Activity Realtionship Chart (ARC)

Stasiun pada proses produksi yang penting didekatkan yaitu gudang bahan baku dengan pengadonan, stasiun ini penting didekatkan karena sesuai aliran kerja pembuatan kue dan menggunakan tenaga kerja yang sama serta menjaga keselamatan tenaga kerja. Selain itu dengan jarak yang terlalu jauh menyebabkan panjangnya waktu yang dibutuhkan untuk membawa bahan baku ke pengadonan. Upaya mendekatkan dua stasiun ini akan mengurangi ceceran tepung pada lantai produksi. Hal ini sesuai dengan penelitian yang dilakukan Mulyati dan Bijir (2014), bahwa analisis ARC yang memiliki aliran kerja penting didekatkan sehingga memperpendek jarak dan waktu perpindahan. Stasiun bahan baku dengan stasiun pencetakan bisa didekatkan karena tidak menimbulkan bahaya dan membantu mempersingkat waktu. Stasiun bahan baku dengan pengggorengan tidak dikehendaki berdekatan dikarenakan dapat menjadi sumber kontaminan bagi bahan baku apabila terkena percikan minyak di penggorengan serta membahayakan keselamatan pekerja. Stasiun bahan baku dengan pengemasan dan penyimpanan bisa didekatakan meskipun tidak ada hubungan kerja tapi tidak menimbulkan bahaya maupun sumber kontaminasi. Hal ini sesuai dengan penelitian yang dilakukan Faishol dkk. (2013) bahwa penempatan stasiun yang memiliki sumber kontaminasi seperti panas, debu ataupun kotoran harus diletakan berjauhan dengan stasiun yang tidak memiliki aliran kerja langsung untuk meminimalisir atau menghindari penyebaran kontaminasi yang dapat merusak kualitas produk.

Stasiun pengadonan dengan pencetakan penting didekatakan kerena merupakan aliran kerja dan material serta menjaga kenyamanan kerja karyawan dalam proses produksi serta mempersingkat waktu produksi. Pengadonan dan penggorengan tidak penting didekatkan karena bukan aliran bahan dan mencegah kontaminasi dan keselamatan kerja. Hal ini sesuai dengan penelitian yang dilakukan Pramesti dkk. (2019) bahwa jarak yang berpotensi menyebabkan kecelakaan kerja juga harus diperhatikan dalam penyusunan rekomendasi layout. Pengadonan dengan pengemasan dan penyimpanan bisa didekatkan meski tidak ada aliran kerja karena tidak menimbulkan hal yang dapat merusak kualitas kue yang ada dipenyimpanan.

Pencetakan/pemberian topping sangat penting didekatkan dengan penggorengan agar kue yang terlambat dicetak dapat langsung digoreng sehingga mengurangi tingkat kontaminasi. Selain itu kedua staisun tersebut merupakan aliran kerja dan material sehingga ketika didekatkan akan memberikan kenyamanan bagi pekerja. Stasiun pencetakan/ pemberian topping bisa didekatkan dengan pengemasan karena tidak menimbulkan kontaminasi bagi bahan yang disimpan di penyimpanan dan pekerja dari kedua stasiun merupakan pekerja yang sama. Stasiun penggorengan dengan pengemasan tidak dikehendaki berdekatan karena stasiun penggorengan memiliki suhu yang tinggi dan percikan 
minyak dapa menimbulkan kontaminasi terhadap bahan yang disimpan dipenyimpanan serta dapat membahaya pekerja yang tengan mengemas kue apa bila terkena percikan minyak.

Hasil analisis ARC kemudian dijadikan acuan untuk rancangan layout baru dengan penggunaan bangunan yang memiliki ukuran yang lebih besar yaitu bangunan 1. Layout usulan disajikan pada Gambar 4.

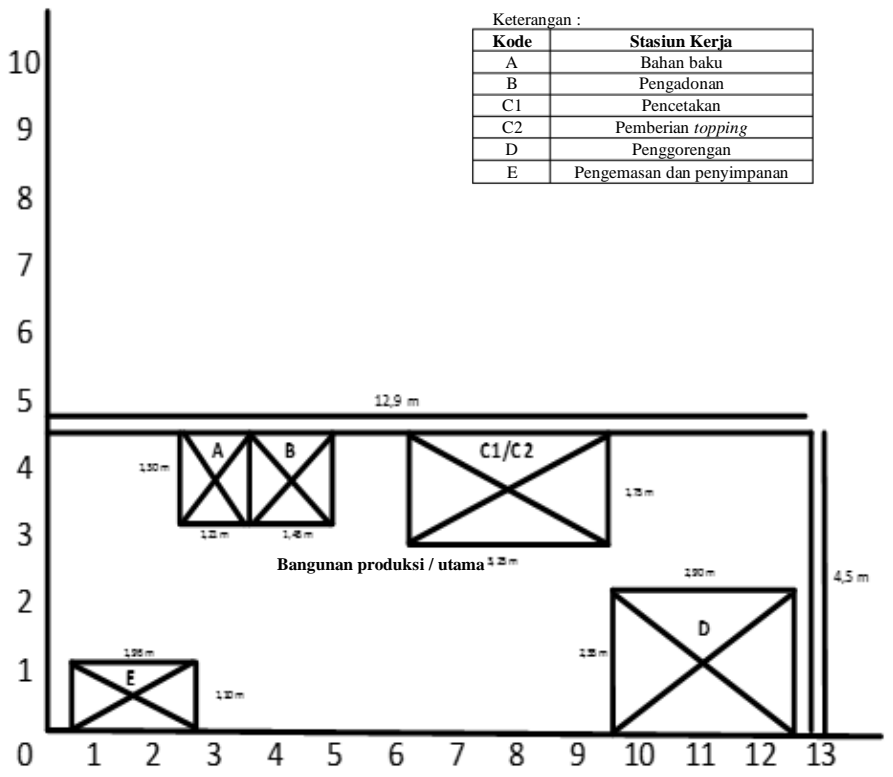

Gambar 4. Layout Usulan

Berdasarkan layout usulan dapat dilihat terdapat perbedaan yaitu bangunan yang digunakan hanya bangunan yang terpisah dari rumah pemilik UD Donesi. Stasiun yang pada kondisi awal di bangunan kedua dirumah pemilik industri dipindahkan kebangunan pertama dan disusun ulang sesuai dengan peta keterkaitan sehingga mempermudah aliran proses dan mempersingkat material handling. Hal ini sesuai dengan Penelitian yang dilakukan Safitril (2017) yang melakukan analisis perancangan tata letak fasilitas produksi menggunakan metode activity relationship chart (ARC) dan hasilnya menunjukkan bahwa layout usulan lebih efektif dan efisien.

\section{Penentuan Titik Koordinat Stasiun Kerja Layout Usulan}

Pemindahan dilakukan untuk mendekatkan dengan stasiun yang berkaitan dan memaksimalkan penggunaan bangunan pertama dan meminimalkan jarak, waktu dan ongkos material handling. Penentuan titik koordinat tiap staiun kerja disajikan pada Tabel 3. Stasiun pencetakan/pemberian topping pada layout awal berada di titik koordinat sumbu $\mathrm{x}=3,8$ dan koordinat sumbu $\mathrm{y}=5,9$. Pada layout usulan titik koorditan stasiun pencetakan/pemberian topping sumbu $\mathrm{x}=7,9$ dan sumbu $\mathrm{y}=3,8$. Untuk stasiun penggorengan pada layout awal titik koordinat sumbu $\mathrm{x}=11,1$ dan sumbu $\mathrm{y}=8,4$. Permindahan yang terjadi di layout usulan yaitu titik koordinta sumbu $\mathrm{x}=11$ dan sumbu $\mathrm{y}=1,1$. Stasiun pengemasan dan penyimpanan pada layout awal titik koordinat sumbu $\mathrm{x}=14,8$ dan sumbu $\mathrm{y}$ $=1,9$. Pemindahan layout usulan titik koordinat sumbu $\mathrm{x}=0,6$ dan sumbu $\mathrm{y}=1,7$ Pemindahan dilakukan untuk mempermudah aliran kerja antar stasiun serta efisiensi daan efektifitas produksi.

Tabel 3. Titik Koordinat Stasiun Kerja Layout Usulan

\begin{tabular}{clcc}
\hline Kode & \multicolumn{1}{c}{ Stasiun kerja } & Koordinat X & Koordinat Y \\
\hline A & Bahan baku & 3 & 3,9 \\
B & Pengadonan & 4,2 & 3,9 \\
C1 & Pencetakan & 7,9 & 3,8 \\
C2 & Pemberian topping & 7,9 & 3,8 \\
D & Penggorengan & 11 & 1,1 \\
E & Pengemasan dan penyimpanan & 0,6 & 1,7 \\
\hline
\end{tabular}




\section{Perhitungan total jarak perpindahan material handling layout Usulan}

Setelah dilakukan penentuan titik koordinat maka dapat dilakukan perhitungan jarak perpindahan seperti Tabel 4. Layout usulan penempatan fasilitas pada alternatif layout mengalami perubahan pada setiap stasiun-stasiun yang ada di UD. Donesi dengan melakukan perhitungan jarak menggunakan rurmus rectilienear, bahwa semua stasiun memiliki pemendekan jarak, pada layout awal adalah 114,9 meter sedangkan layout usulan 46,4 meter. Hasil tersebut menunjukan bahwa layout usulan lebih efektif dan dapat mempersingkat jarak material handling serta memaksimalkan fungsi bangunan pertama. Hal ini sesuai dengan. Penelitian yang dilakukan Amalia.R.R.,dkk (2017) dengan menggunakan metode ARC (Activity Relationship Chart) serta rumus Rectalinier mampu meminimumkan jarak material handling pada industry pengolahan tahu.

Tabel 4. Total jarak perpindahan material handling layout Usulan

\begin{tabular}{cccc}
\hline Stasiun kerja dari-ke & Jarak antar stasiun kerja & $\begin{array}{c}\text { Frekuensi } \\
\text { Pemindahan/ hari }\end{array}$ & $\begin{array}{c}\text { Jarak tempuh/ } \\
\text { hari }\end{array}$ \\
\hline A-B & 1,2 & 2 & 2,4 \\
B-C1 & 3,8 & 3 & 11,4 \\
C1-D & 5,8 & 2 & 11,6 \\
D-C2 & 5,8 & 2 & 11,6 \\
C2-E & 9,4 & 1 & 9,4 \\
\hline
\end{tabular}

\section{E. Perhitungan Ongkos Material Handling Layout Usulan}

Perhitungan ongkos material handling adalah dengan menentukan ongkos dari stasiun satu ke stasiun yang lain dengan menggunakan alat angkut manusia yang disajikan pada Tabel 5. Ongkos material handling pada layout usulan disesuaikan dengan analisis ARC. Ongkos Material Handling yang diperoleh dari layout awal adalah Rp 49.995 sedangkan layout Usulan Rp 29.331. Hasil tersebut menunjukan bahwa layout usulan dapat mengurangi ongkos material handling antar stasiun sebesar $58,67 \%$. Hal ini sesuai dengan penelitian yang dilakukan Safitri dkk. (2017) yang melakukan perancangan tata letak fasilitas menggunakan metode ARC dan hasilnya adalah dapat menghemat biaya perusahaan setiap bulannya hingga beberapa persen dan output yang dihasilkan lebih optimal sehingga layout usulan lebih efektif dan efisien.

Tabel 5.Ongkos Material Handling Layout Usulan

\begin{tabular}{cccc}
\hline \multicolumn{3}{c}{ Aliran proses } & OMH \\
\hline Dari & Ke & (Rp) \\
\hline A & B & 9.320 \\
B & & C1 & 1.919 \\
C1 & & C 2 & 5.916 \\
D & & E & 5.916 \\
C2 & & 6.260 \\
\hline & Total & & 29.331 \\
\hline
\end{tabular}

\section{F. Perhitungan Waktu Material Handling Layout Awal}

Waktu perpindahan bahan merupakan hal yang penting dalam proses produksi. Perhitungan waktu berfungsi untuk mengetahui total waktu perpindahan dari stasiun satu ke stastiun lainnya Pramesti dkk. (2019). Waktu material handling layout usulan disajikan pada Tabel 6.

Tabel 6. Waktu Material Handling Layout Usulan

\begin{tabular}{|c|c|c|c|c|c|}
\hline \multicolumn{2}{|c|}{ Aliran proses } & \multirow{2}{*}{$\begin{array}{c}\text { Total jarak } \\
\text { (meter) }\end{array}$} & \multirow{2}{*}{ Frekuensi } & \multirow{2}{*}{$\begin{array}{c}\text { Total waktu per } \\
\text { meter (detik) }\end{array}$} & \multirow{2}{*}{$\begin{array}{l}\text { Total waktu } \\
\text { (detik) }\end{array}$} \\
\hline Dari & $\mathrm{Ke}$ & & & & \\
\hline A & B & 2,4 & 2 & 2,3 & 5,52 \\
\hline B & $\mathrm{C} 1$ & 11,4 & 3 & 5,3 & 60,42 \\
\hline $\mathrm{C} 1$ & D & 11,6 & 2 & 4,9 & 56,84 \\
\hline D & $\mathrm{C} 2$ & 11,6 & 2 & 4,9 & 56,84 \\
\hline $\mathrm{C} 2$ & E & 9,4 & 1 & 4,5 & 42,3 \\
\hline
\end{tabular}


Layout usulan dapat meminimalkan waktu proses pemindahan bahan sebesar 358,46 detik. Proses pemindahan bahan dari stasiun ke stasiun dapat menghemat waktu dengan cara mengurangi jarak perpindahan tersebut. Waktu proses pemindahan bahan merupakan hal yang penting dalam suatu proses produksi. Adapun waktu yang dibutuhkan dalam proses pemindahan bahan pada layout awal dalam satu kali produksi. Dapat diketahui total waktu yang dibutuhkan pada layout awal total waktu yang dibutuhkan pada proses pemindahan bahan dalam satu hari adalah 580,38 detik sedangkan pada layout usulan 221,92 detik.

\section{G. Perbandingan Layout Awal dan Layout Usulan}

Hasil yang didapat terkait jarak perpindahan, waktu dan ongkos material handling antara layout awal dan layout usulan yang telah dibandingkan dapat dilihat pada Tabel 7 berikut.

Tabel 7. Perbandingan Layout Awal dan Layout Usulan

\begin{tabular}{cccccccc}
\hline \multicolumn{2}{c}{ Aliran Proses } & \multicolumn{3}{c}{ Hasil Layout Awal } & \multicolumn{3}{c}{ Hasil Layout Usulan } \\
\hline Dari & Ke & $\begin{array}{c}\text { Jarak } \\
(\mathrm{m})\end{array}$ & $\begin{array}{c}\text { OMH } \\
(\mathrm{Rp})\end{array}$ & $\begin{array}{c}\text { Waktu } \\
(\text { detik })\end{array}$ & $\begin{array}{c}\text { Jarak } \\
(\mathrm{m})\end{array}$ & $\begin{array}{c}\text { OMH } \\
(\mathrm{Rp})\end{array}$ & $\begin{array}{c}\text { Waktu } \\
(\text { detik })\end{array}$ \\
\hline A & $\mathrm{B}$ & 2,6 & 9.999 & 5,98 & 2,4 & 9.320 & 5,52 \\
$\mathrm{~B}$ & $\mathrm{C} 1$ & 59,4 & 9.999 & 314,82 & 11,4 & 1.919 & 60,42 \\
$\mathrm{C} 1$ & $\mathrm{D}$ & 19,6 & 9.999 & 96,04 & 11,6 & 5.916 & 56,84 \\
$\mathrm{D}$ & $\mathrm{C} 2$ & 19,6 & 9.999 & 96,04 & 11,6 & 5.916 & 56,84 \\
C2 & $\mathrm{E}$ & 15 & 9.999 & 67,5 & 9,4 & 6.260 & 42,3 \\
\hline \multicolumn{2}{c}{ Total } & 114,9 & 49.995 & 580,38 & 46,4 & 29.331 & 221,92 \\
\hline
\end{tabular}

Berdasarkan hasil perancangan ulang tata letak menggunakan metode ARC dan dianalisis secara kuantitatif berupa perhitungan jarak, waktu dan ongkos material handling. Setiap stasiun pada layout awal dan layout usulan maka dibandingan semua hasil yang didapat sehingga mendukung rancangan tata letak yang lebih efisiean dan efektif bagi industri tersebut.

Pada layout awal jarak material handling dari hasil perhitungan adalah 114,9 meter dengan ongkos material handling sebesar Rp 49.995 dan waktu yang dibutuhkan adalah 580,38 detik. Sedangkan Pada layout usulan jarak material handling dari hasil perhitungan adalah 46,4 meter dengan ongkos material handling sebesar Rp 29.331 dan waktu yang dibutuhkan adalah 221,92 detik. Dari hasil perhitungan tersebut telihat perbedaan yang lumayan signifikan dimana layout usulan dapat memperpendek jarak dan waktu perpindahan dan mengurangi ongkos material handling dalam proses produksi. Hal ini sesuai dengan Penelitian yang dilakukan Safitril (2017) yang melakukan perbandingan antar layout awal dan layout usulan yang telah dianalisis menggunakan metode activity relationship chart $(A R C)$ dan hasilnya menunjukkan bahwa layout usulan hasil penelitian lebih efisien, waktu pengerjaan yang optimal, dapat menghemat biaya perusahaan setiap bulannya dan output yang dihasilkan lebih optimal. Penelitian yang dilakukan Setiyawan dkk. (2017) menunjukkan bahwa layout usulanharus memberikan kontribusi untuk mengurangi waktu siklus produksi penanganan material dan dapat meningkatakan output produksi.

\section{KESIMPULAN}

Rancangan ulang tata letak di UD. Donesi berdasarkan analisis Activity Relationship Chart (ARC) menggunakan 1 bangunan utama untuk proses produksi dengan luas 4,5 x 12,9 meter. Hasil perhitungan layout awal dan layout usulan didapatkan bahwa layout usulan memiliki hasil perhitungan jarak, waktu dan ongkos material handling yang lebih efektif dan efisien. Efisiensi yang terjadi adalah selisih jarak sebesar 68,5 meter, total waktu sebesar 356,46 detik dan selisih total ongkos material handling sebesar Rp 20.664.- terhadap layout awal. 


\section{DAFTAR PUSTAKA}

Amalia, R. R., Ariyani, L., \& Noor, M. (2017). Perancangan Ulang Tata Letak Fasilitas Industri Tahu Dengan Algoritma Blocplan di UD. Pintu Air. Jurnal Teknologi Agro-Industri. Vol. 4 (2): 89100. doi: $10.34128 /$ jtai.v4i2.54.

Astuti, M., Poerwanto, E., \& Trianingsih, A. (2017). Analisis Tata Letak Fasilitas Dengan Menggunakan Metode Activity Relationship Chart Pada Industri Mebel Bambu Karya Manunggal Yogyakarta. Prossiding SENATIK. Vol. III: 112-116.

Erni, N., Widodo, L., \& Poala, Y. (2013). Usulan Perancangan Ulang Tata Letak Pabrik Pada Pt. XYZ. Jurnal Ilmiah Teknik Industri. Vol. 1 (3): 1-13. doi: 10.24912/jitiuntar.v1i3.479

Faishol, M., Hastuti, S., \& Ulya, M. (2013). Perancangan Ulang Tata Letak Fasilitas Produksi Pabrik Tahu Srikandi Junok Bangkalan. Agrointek Jurnal Teknologi Industri Pertanian. Vol.7 (2): 57-65. doi: 10.21107/agrointek.v7i2.2051

Maydah, Darmawan, M.I., \& Ilmannafian, A.G. (2020). Studi Komparasi Metode EOQ Dan POQ Dalam Efisiensi Biaya Persediaan Tepung Terigu Di PT. XYZ. Jurnal Teknologi AgroIndustri. Vol. 7 (2): 121-131. doi: 10.34128/jtai.v7i2.120

Mulyati, D., \& Bijir. (2014). Optimalisasi Tata Letak Mesin Produksi Terhadap Kinerja Karyawan Pada CV. ABC Aceh Besar . Industrial Engineering Jornal. Vol. 3 (2): 4-9.

Pramesti, M., Subagyo, H. S., \& Aprilia, A. (2019). Perancangan Ulang Tata Letak Fasilitas Produksi Nangka Dan Usulan Keselamatan Kesehatan Kerja di UMKM Duta Fruit Chips, Kabupaten Malang. Agrisocionomics Jurnal Sosial Ekonomi dan Kebijakan Pertanian. Vol. 3 (2): 150164.

Pratiwi, I., Muslimah E., \& Aqil, W. A. (2012). Perancangan Tata Letak Fasilitas di Industri Tahu Menggunakan Blocplan. Jurnal Ilmiah Teknik Industri, Vol. 11,(2):102-112.

Safitril, Dini, N., Ilmi, Zainal, Kadafi, \& Amin, M. (2017). Analisis Perancangan Tataletak Fasilitas Produksi Menggunakan Metode Activity Relationship Chart (ARC). Jurnal Manajemen. Volume 9 (1): 38-47.

Setiyawan, D. T., Qudsiyyah, D. H., \& Mustaniroh, S. A. (2017). Usulan Perbaikan Tata Letak Fasilitas Peroduksi Kedelai Goreng Dengan Metode Blocplan Dan Corelap . Industria: JurnalTeknologi dan Manajemen Agroindustri. Vol. 6 (1): 51-60. doi: 10.21776/ub.industria.2017.006.01.7

Yulianti, R., Saleh, A., \& Bakar, A. (2014). Usulan Perancangan Tata Letak Fasilitas Perusahaan Garmen CV.X Dengan Menggunakan Metode Konvensional. Reka Integra: Jurnal Online Teknik Industri Itenas. Vol. 02 (3): 72-83. 